\title{
Bulky Vehicles Recycling. Part 1 - Conditions for Recycling
}

\author{
Recykling pojazdów wielkogabarytowych. Część 1 - warunki recyklingu
}

\author{
Anna Matuszewska ${ }^{1}$, Piotr Wieczorek ${ }^{2}$, Izabela Samson-Bręk ${ }^{3}$ \\ ${ }^{1}$ Faculty of Christian Philosophy, Cardinal Stefan Wyszyński University in Warsaw, Poland \\ ${ }^{2}$ Automotive Industry Institute, kukasiewicz Research Network, Warsaw, Poland \\ ${ }^{3}$ Institute of Environmental Protection - National Research Institute, Łukasiewicz Research Network, Warsaw, Poland \\ ORCID: AM https://orcid.org/0000-0002-7853-7401; PW https://orcid.org/0000-0002-7605-9733; \\ IS-B https://orcid.org/0000-0002-3082-5703•a.matuszewska@uksw.edu.pl \\ Received: 26 July 2020; Revised: 29 Sep 2020; Accepted: 09 0ct 2020
}

\begin{abstract}
Recycling of end-of-life passenger vehicles is a well-known topic, and there are many literary reports in this regard. However, little information is available on the recycling of bulky vehicles, which determines the authors' intention to present this issue. This article describes the loopholes that have prevented end-of-life vehicles from currently being recycled. The forms of recycling of these types of vehicles has been shown, and they are analogous to those for passenger cars. Also being presented are the causes of design changes in passenger cars and trucks, with the reasons for these changes being slightly different in bulky vehicles, than in passenger cars, and the article will discuss how these changes translate into recycling. Examples of actions taken by large vehicle manufacturers to meet the changes taking place in the economy, and implement the principles of the circular economy, in the field of recycling large-size vehicles, are also outlined.
\end{abstract}

Keywords: recycling, truck, road tractor

Streszczenie: Recykling pojazdów osobowych wycofanych z eksploatacji jest tematem znanym i w tym zakresie można znaleźć wiele doniesień literaturowych. Natomiast niewiele informacji jest dostępnych na temat recyklingu pojazdów wielkogabarytowych, dlatego intencją autorów było przedstawienie tego zagadnienia. W tym artykule opisano luki prawne, które spowodowały, że pojazdy wycofane z eksploatacji nie są obecnie objęte wymogiem recyklingu. Wykazano, jakie są formy recyklingu tego typu pojazdów i że są one analogiczne jak dla samochodów osobowych. Przedstawiono także, jakie są przyczyny zmian konstrukcyjnych w samochodach osobowych i ciężarowych, że przyczyny tych zmian są nieco odmienne w pojazdach wielkogabarytowych niż w osobowych i omówiono jak te zmiany przekładają się na recykling. Przedstawiono także przykłady działań podejmowanych przez dużych producentów pojazdów, które wychodzą naprzeciw zmianom zachodzącym w gospodarce i wdrażają zasady gospodarki o obiegu zamkniętym w zakresie recyklingu pojazdów wielkogabarytowych.

Słowa kluczowe: recykling, pojazd ciężarowy, ciągnik drogowy 


\section{Introduction}

A significant number of vehicles move on our roads transporting various types of cargo. Vehicles whose loading part is their integral part are called trucks, whereas those with a total vehicle weight of less than 3.5 tons are classified as vans (Chłopek et al. $2017,5)$. These cars can be further divided by body type into: cars with a universal load box that can be covered with a sheet (box vehicles); cars with closed box (closed boxes); cars with tipping body (dump trucks) and cars with specialized bodies adapted for the carriage of specific loads or in a certain way (e.g. refrigerated trucks, tanks, animals, cars etc.). Road tractors are the second group of vehicles designed to transport loads. These are structurally designed vehicles exclusively for towing a trailer or semi-trailer. This group includes tractors intended for hauling semi-trailers and road tractors (e.g. ballast tractor) - intended for hauling trailers other than semi-trailers. A detailed breakdown of all road vehicles together with their definitions is provided in the Directive (Directive 2007/46/EC) and amended by the Regulation of the European Commission (Regulation 678/2011). The aforementioned Directive also includes the letter classification of vehicles regarding the approval category. Pursuant to Annex II of the Directive, vehicles intended for the carriage of goods are classified in category $\mathrm{N}$ and trailers (including semi-trailers) in category $\mathrm{O}$, in which there are additional subcategories (Chłopek et al. 2017, 5).

All end-of-life vehicles are treated as waste. The handling of such vehicles is governed by the relevant EU Directive (Directive $2000 / 53 / E C)$. This document obliged all EU countries to reuse and recover at least $95 \%$ of the weight of the vehicle and recycling at least $85 \%$ of the weight of the vehicle from 2015. Pursuant to this Directive, Member States are encouraged to select vehicle construction materials in such a way that they contain as little hazardous materials as possible that the vehicle components are constructed in such a way as to enable their disassembly as easily as possible and that as much of the materials used in the vehicle as possible are made of materials derived from recycling. The Directive also obliges vehicle manufacturers to facilitate recycling, parts and materials used in the construction of the vehicle are marked, to enable their identification and that manufacturers provide vehicle processing plants with information on dismantling, and in particular about the hazardous materials used. This document recommends that in order to improve recycling, before removing all removable elements, including tires, should be removed from the vehicle. The Polish document, taking into account the provisions of Directive 2000/53/EC and regulating the treatment of end-of-life vehicles is the Act on the recycling of endof-life vehicles (Act 2005).

Both Directive 2000/53/EC on end-oflife vehicles and the Act on the recycling of end-of-life vehicles from 2005 apply only to passenger cars and vehicles designed and constructed for the carriage of goods whose maximum weight does not exceed 3.5 tonnes (vehicles in the $M_{1}$ and $N_{1}$ category). Both legal acts are still in force. The approval classification, taking into account categories $\mathrm{M}_{2}, \mathrm{M}_{3}, \mathrm{~N}_{2}, \mathrm{~N}_{3}$ and $\mathrm{O}_{1}, \mathrm{O}_{2}, \mathrm{O}_{3}$ and $\mathrm{O}_{4}$ (for buses, other types of trucks and trailers), was introduced in 2007 (Directive 2007/46/EC). The provisions of this directive have not been implemented into pre-existing legal acts, therefore the obligation to recycle does not apply to vehicles other than categories M1 and N1. The pursuit of the European Union to pursue a closed-cycle economy will in the future force the use of recycling for all types of vehicles, including heavy goods vehicles. All the more so because there is already a lot of pressure on vehicle manufacturers and their components to use recyclates in the largest possible quantity in their production.

\section{End-of life trucks}

Every year, 7 to 8 million tons of various waste (European Commision 2020) is generated from end-of-life vehicles in the 
European Union, including hazardous waste e.g. operating fluids or batteries. This amount is constantly increasing due to the increasing number of vehicles on the road. According to the Central Register of Vehicles and Drivers statistics (in Polish Centralnej Ewidencji Pojazdów i Kierowców - CEPiK), a steady increase in the number of endof-life vehicles is also observed in Poland Table 1. It should be borne in mind that not all vehicles are deregistered end-of-life vehicles - some of them were e.g. stolen or taken abroad.

Large vehicles, as well as passenger cars are recycled after being out of service. However, due to the size and general construction other than passenger cars, the dismantling of these vehicles is also slightly different. The overall construction system of vehicles intended for the carriage of goods is similar. Such a vehicle consists of two main parts the frame chassis and the body, whose appearance depends on the purpose of the car. The truck frame is the main element of the car's supporting structure and the loads acting on such a vehicle are transferred completely or partially by it. The utility body, cab, drive system, suspension, fifth wheel coupling device or fuel tanks are attached to the frame. The wheels are connected to the frame by suspension. The engine is mounted in the front of the frame.

In the case of trailers, the construction of the chassis is a much simpler structure than the chassis of the car. The lack of the need for drive means that the chassis consists only of load-bearing, traveling and control mechanisms, and in its design you can distinguish a support frame, a tow bar, axle wheels with suspension as well as brake and lighting installation with connections (Prochowski and Żuchowski 2004, 24). A semi-trailer is a type of trailer. It is characterized by the lack of a front axle, and its front part rests on the tractor and loads the vehicle, while the other end rests on the trailer's wheels. It differs from the trailer by the coupling mechanism - it is a slide plate with a king pin (used to connect with the fifth wheel) and the fifth wheel which is located on the frame of the fifth wheel tractor. The types of semi-trailers and trailers are very similar. There are standard and specialized semi-trailers and trailers (e.g. for transporting animals, cisterns, silos, with moving floors, etc.) and refrigerated trucks.

\section{Types of vehicle recycling}

In the case of bulky vehicles, similarly to passenger cars, three types of recycling

Table 1. Deregistered vehicles by type in individual years (CEPiK 2020)

\begin{tabular}{lrrrrrrr}
\hline \multicolumn{1}{c}{ Type of car/year } & 2007 & 2008 & 2009 & 2010 & 2011 & 2012 & 2013 \\
\hline Bus/coach & 2646 & 2702 & 2319 & 2194 & 3818 & 11510 & 4369 \\
\hline Agricultural tractor & 930 & 711 & 549 & 367 & 522 & 646 & 779 \\
\hline Car tractor & 3773 & 4279 & 3137 & 3232 & 4103 & 4431 & 3252 \\
\hline Motorcycle & 1041 & 1176 & 1479 & 1041 & 1245 & 1726 & 2329 \\
\hline Motorbike & 1977 & 2416 & 2754 & 2600 & 3246 & 3767 & 4175 \\
\hline Truck semitrailer & 3276 & 3297 & 2443 & 2691 & 3168 & 3487 & 2875 \\
\hline Special semitrailer & 45 & 44 & 42 & 47 & 57 & 49 & 53 \\
\hline Trailer & 1261 & 1272 & 1170 & 985 & 1252 & 1643 & 1477 \\
\hline Agricultural trailer & 251 & 271 & 206 & 180 & 154 & 191 & 471 \\
\hline Light trailer & 1429 & 1830 & 1873 & 1486 & 1577 & 1550 & 1916 \\
\hline Special trailer & 318 & 390 & 382 & 320 & 378 & 462 & 580 \\
\hline Car other & 28 & 45 & 85 & 101 & 78 & 93 & 139 \\
\hline Truck & 24669 & 25626 & 24684 & 26607 & 32138 & 37457 & 38128 \\
\hline Car & 182153 & 196932 & 204867 & 222050 & 288409 & 332840 & 383567 \\
\hline Special car & 1307 & 1540 & 1652 & 1680 & 2178 & 2270 & 2113 \\
\hline Trolley bus & 20 & 10 & 6 & 7 & 29 & 17 & 28 \\
\hline
\end{tabular}


are used: product, material and energy (Bocheński 2004, 20).

Product recycling involves the re-use of parts or vehicle components that are in good condition with little wear. There are two varieties:

- direct product recycling, which consists in dismantling and reusing dismantled parts in other vehicles; this is the simplest form of recycling,

- product recycling with parts regeneration, which consists in restoring performance by regenerating them and reusing them in other vehicles.

With this form of recycling, it is necessary to assess the technical condition of the dismantled elements to determine whether regeneration is profitable and whether we will obtain a product of the assumed quality after regeneration. It is assumed that the strength of the element after regeneration should be not less than $80 \%$ in relation to the new element (Recycling 2020).

Material recycling of the vehicle is carried out after dismantling the parts and components that can be used in product recycling. It involves fragmentation of the wreck, segregation of obtained materials and their transfer to processing plants. Vehicle processing used materials into a product with properties similar to the original one. Shredding the wreck is carried out in the so-called shredding process. It is a mechanical process that takes place in industrial mills, as a result of which vehicle wrecks are fragmented into elements of various sizes. The shredded material can then be separated into individual fractions.

The separated fractions can be used to produce new material, but this material may have worse technical parameters (e.g. strength) than the original material. Such material can be reused in the automotive industry, but for a different purpose than the previous one. This material can be used to produce elements for which the technical requirements are lower, e.g. from polypropylene bumpers, covers for ventilation ducts can be produced. The recovered materials can also be used in other industries, e.g. material from tires for the production of floor coverings or as an addition to asphalt.

Energy recycling is the recovery of energy accumulated in materials by burning them. Such materials are subject to such recycling, where material recycling is not very profitable (e.g. the use of advanced processing technologies is required). The most commonly used materials in this form of recycling include: tires, used oils, plastics and shredder residues (Alwaeli 2016, 191).

Specialized companies deal with vehicle recycling. After admission, the vehicles are washed, dried, diagnosed, sorted and stored (Chłopek 2012, 133-147). Then they are disassembled. At the beginning of the vehicle operating fluids are removed from the vehicle (cooling, brake and washer fluids, lubricating oils, fuel, oil from shock absorbers, etc.). Due to the ease of penetration into the ground and harmful flow to the environment (in particular lubricating oils and refrigerants), the removal of operating fluids must be carried out with extreme caution. Some liquids are recycled and the rest is utilized (energy recycling).

In the next stage, the vehicle is examined to determine (assess) parts or components that can be reused. Parts that are easy to demolish (wheels, batteries, windows, mirrors) are removed from the vehicle, assemblies and components of the vehicle are removed, as well as equipment and other parts (engine, seats, upholstery, electric wires). Body components (doors, bonnets, bumpers, roof) that are in good condition are also dismantled for reuse. Dismantled solid components are qualified for their further recycling, i.e. whether they are intended for reuse, regeneration, material recovery or comminution (shredding). The part of the vehicle remaining after dismantling (wreckage) is intended for shredding and is often subjected to crushing to minimize storage costs. A diagram of the vehicle recycling process is shown in Figure 1: 


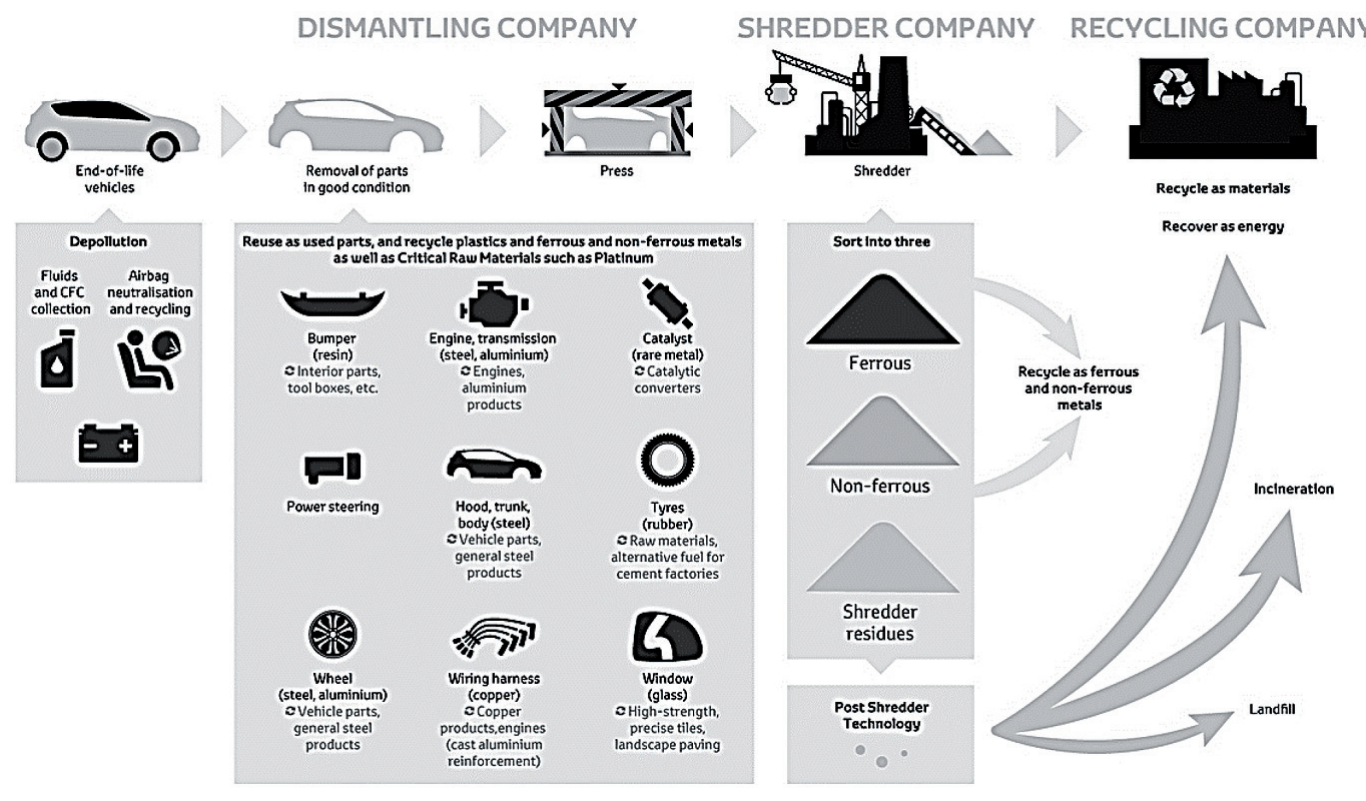

Figure 1. Vehicle recycling stages (Toyota 2020)

Recovered parts that cannot be reused are sorted by material (e.g. iron, aluminium, brass, copper, plastics) and sent for further processing or shredding together with the wreck of the vehicle. The crushed material is separated into various fractions (ferrous metals, non-ferrous metals, plastics), which are then sent for recycling. The combustible part, which is not used in other forms of recycling of shredding fractions, is subject, as an additive to fuels (together with some operating fluids) to energy recovery in furnaces in metallurgy or cement plants. The remainder goes to landfills.

\section{Impact of vehicle design changes on recycling}

In recent years, the share of individual types of materials used in vehicle construction has changed. The reasons for this are, among others: striving to reduce the weight of the vehicle (which results in lower fuel consumption and lower carbon dioxide emissions (Conradie et al., 2018, 5)), introducing new materials with better properties, adapting materials to changing vehicle performance, introducing new materials together with new solutions (e.g. changing the power supply from internal combustion engines to electric ones, changing the fuel used from liquid to gas) (Kanari 2003, 15). In addition, more and more often, when designing new vehicles, the selection of materials is taken into account so that dismantling, reuse and recycling of end-of-life vehicles can be crried out relatively easily. The use of modern materials in heavy goods vehicles has a slightly different reason than in passenger cars. In addition to reducing the weight of the vehicle, which results in lower fuel consumption and lower carbon dioxide emissions, the emphasis is on increasing strength, fatigue wear and operating time. Trucks are heavily exploited vehicles designed to carry heavy loads over long distances. For this reason, more and more elements made of high strength steel, polymers containing carbon fibers in the constructions of support elements, elements of the cabin and leaf springs, as well as light metals (aluminum, magnesium) in the fasteners appear in the chassis and cabin load-bearing structures. For example, in modern Scania trucks, cylinder blocks are made of gray cast iron, as in the vehicles of the 196os. Load-bearing components such as frames, beams and 
bodies are also still made of steel. However, the steels used today are much more durable and tighter. As a result, the elements manufactured from it may have smaller dimensions than those produced earlier (Scania 2015).

Aluminum is one of the materials used to reduce the weight of trucks. The share of this material in the design and construction of the vehicle is increasing. This metal is used as a component of cabins, doors, fuel tanks, superstructure elements, bumpers, trailer construction elements and others. Modern trucks contain from $500 \mathrm{~kg}$ to $3,000 \mathrm{~kg}$ of aluminum, depending on the type of vehicle - on average this amount is $1000 \mathrm{~kg}$ (European Aluminum Association 2014). Life cycle analyzes conducted by the European Aluminum Association have shown that $\mathrm{CO}_{2}$ reduction potential of aluminium for articulated trucks, taking production, use and end-of-life recycling stages into account, is as follows (European Aluminium Association 2014):

- $1 \mathrm{~kg}$ of aluminium in today's average truck enables to saves $26 \mathrm{~kg}$ of $\mathrm{CO}_{2}$,

- the use of another kilogram of aluminum in the construction of tomorrow's truck would save about $19 \mathrm{~kg}$ of $\mathrm{CO}_{2}$,

- $1 \mathrm{~kg}$ of aluminium in an urban bus reduces emissions of $\mathrm{CO}_{2}$ by about $40 \mathrm{~kg}$.

Increasing the strength and thus the life of the vehicle elements meant that more and more parts disassembled from endof-life cars can be reused. For example, in France in 2015 (Monier and Benhallam 2017), as a result of dismantling, materials and parts constituting $21.9 \%$ of the vehicle weight were recovered ( $21.1 \%$ in 2014$)$, the rest was a wreck. Of these dismantled parts, $39.7 \%$ in 2015 and $39.5 \%$ in 2014 (excluding batteries and tyres) were materials and parts directed for reuse, and $32.8 \%$ (32.1\% in 2014) materials and parts directed for recycling or regeneration. Obtained wrecks were sent to shredders but in $2015,13 \%$ less tonnes of wrecks were shredded than in 2014. In turn, in produced in the United States light-duty vehicles the share of aluminum in vehicle construction from 1995 to 2014 increased from approx. $6 \%$ to $10 \%$, high and medium strength steel from ca. $9 \%$ to ca. $16 \%$, and in the case of steel and iron castings there was a decrease in the share of these materials from approx. $46 \%$ to $37 \%$ and from $12 \%$ to $7 \%$ respectively (Dai and Elgowainy 2016).

Extending the life of truck components has led to their cost-effective recovery and some vehicle manufacturers have themselves started recycling their own brands. An example of such a company is Volvo Trucks, which in Gothenburg at Volvo Truck Center disassembles end-of-life trucks. The works are carried out manually and 30 to 40 vehicles are dismantled annually. For example, dismantling the Volvo FH 4,6o Euro 3 takes six to seven days. The truck is dismantled 'from front to back'. First, the elements are removed from and around the booth, including liquids, which are drained into tanks and intended for disposal. Then the cabin is dismantled - cabins up to 10 years old are most often sold, while the older ones are intended for smelting in smelters. The components in good condition are sold on the used parts market. Elements that are not suitable for reuse are sorted by type of material and sent to companies dealing with their processing, e.g. to steel mills. About a third of the materials used in the production of a new Volvo truck come from raw materials recovered in the recycling process. The company's vehicles are designed and manufactured in such a way that about $90 \%$ of the vehicle's mass can be recycled (Volvo Truck Corporation 2020).

Similar solutions and technologies have been identified at Scania. Within this group, Scania Vehicle Recycling has been established, which deals with the dismantling and recycling of Scania trucks Figure 2. Many vehicle components that are in good condition (e.g. engines, gearboxes or differential mechanisms) are subject to checking, regeneration and internal adjustment. Scania Vehicle Recycling has 


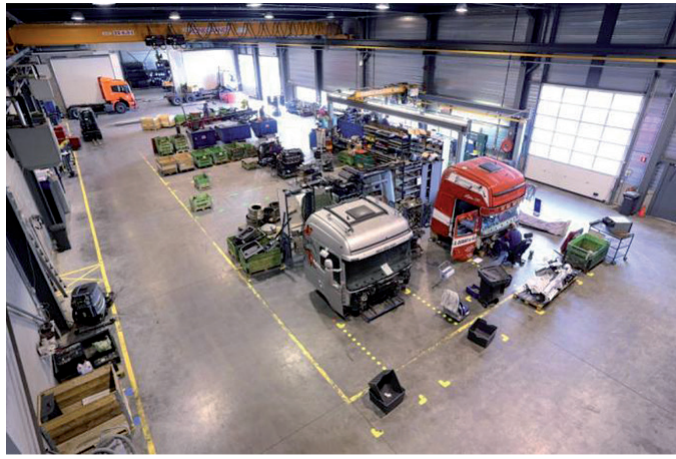

Figure 2. Truck recycling Scania (ScaniaVehicle Recycling 2020)

on offer a wide range of recycled parts (Scaniausedparts.com. 2020).

The same goes for the MAN concern, under which MAN Genuine Parts deals with disassembly, regeneration and sale of parts recovered from vehicles (Services Man, 2020a). The list of the most frequently recovered elements is presented in Figure 3.

\section{Conclusion}

The growing number of vehicles on the road, both passenger and heavy, will generate an increasing number of end-of-life vehicles. All end-of-life vehicles are treated as waste. The handling of such vehicles is governed by the relevant directives and laws only that after the amendments they apply only to passenger vehicles and vehicles for the carriage of goods, whose maximum weight does not exceed 3.5 tonnes. The obligation to recycle does not apply to bulky vehicles (trucks, buses). However, the EU's pursuit of a circular economy will require recycling also for this group of vehicles. Already, pressure is being exerted on producers of large-size vehicles to use as much as possible of elements made from recyclates in their production. Large-size vehicles are subject to the same recycling methods as passenger vehicles, i.e. product, material and energy vehicles, and they are implemented by specialized companies.

New vehicle construction solutions, adapting materials to changing vehicle

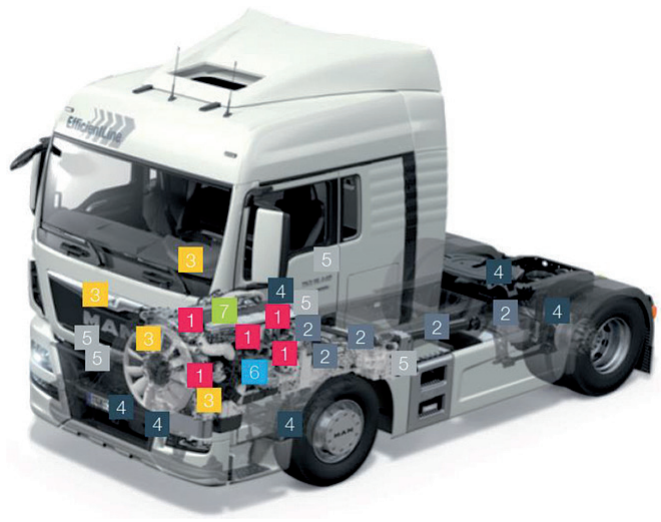

Figure 3. List of the most frequently recovered elements from Man vehicles (Services Man 2020b):

1. Engine [red]: turbocharger, crankshaft, engine/short block, flywheel, cylinder head 2. Driveline [yellow]: final drive, propshaft, clutch, power take-off, transfer case, gearbox 3. Electrical system [deep blue]: tachograph, alternator, starter

4. Frame [blue]: Steering gear, Power steering pump, Steering

5. Air/brake [green]: Brake calliper, Brake cylinder, EBS modules, Air compressor, Air dryer, Brake valves

6. Cooling system: refrigerant compressor, coolant pump

7. Fuel/exhaust gas: CR-injector, particulate filter, nozzle holder, injection pump, supply module DeNOx

performance, introducing new materials are mainly aimed at reducing the vehicle's weight and reducing carbon dioxide emissions (Synák et al. 2019, 41). In addition to the aforementioned, an important reason for these activities is also the extension of the vehicle's service life (increasing strength and resistance to fatigue wear). In the case of large-size vehicles, the purpose of structural changes is to increase strength, resistance to fatigue and extend the life of the vehicle. Thus, in this type of vehicles, more and more elements made of high-strength steel, polymers containing carbon fibres or light metals are used. As a result, the recovery of truck construction elements has become profitable and some companies have introduced 
into their operations the recycling of end-oflife cars of their own brands. After cleaning and possible renovation, these elements are installed in new vehicles. Such actions not only reduce production costs, but also improve the company's image through its contribution to the circular economy.

\section{Bibliography}

Act 2005 - Act of 20 January 2005 on the recycling of end-of life vehicles. (U. 2005, No. 25, item 2020) (Dz.U. Journal of Laws of the Republic of Poland). Alwaeli, Mohamed. 2016. "End-of-life vehicles recovery and recycling and the route to comply with EU directive targets." Environment Protection Engineering 42(1): 191-202. https://doi.org/10.5277/ epe160114.

Bocheński, Cezary I. 2004. "Recykling pojazdów samochodowych." Recykling 6: 20-22.

CEPiK. Accessed April 20, 2020. http://www.cepik. gov.pl/.

Chłopek, Zdzisław, Katarzyna Bebkiewicz, Krystian Szczepański, and Magdalena Zimakowska. 2017. "Assessment of results of pollutant emission inventory of the road transport sector in Poland in 2000-2015." The Archives of Automotive Engineering 78(4): 5-25. https://doi.org/10.14669/ AM.VOL78.ART1.

Chłopek, Zdzisław. 2012 Ekologiczne aspekty motoryzacji i bezpieczeństwo ruchu drogowego. Warszawa: Wydawnictwo Politechniki Warszawskiej.

Conradie, Pieter Daniel Francois, Olabanji Olumuyiwa Asekun, Tomáš Skrúcaný, Martin Kendra, and Ondrej Stopka. 2018. "The effect of fuel on the energy consumption and production of greenhouse gases in transport." The Archives of Automotive Engineering 82(4): 5-14. https://doi. org/10.14669/AM.VOL82.ART1.

Dai, Qiang, Jarod Kelly, and Amgad Elgowainy. 2016. Vehicle materials: material composition of U.S. light-duty vehicles. Washington, D.C.: Argonne National Laboratory. Accessed April 22, 2020. https://greet.es.anl.gov/files/ light-duty-vehicle-2016.

Directive 2000/53/EC - Directive 2000/53/EC of the European Parliament and of the Council of 18 September 2000 on end-of life vehicles Commission Statements.
Directive 2007/46/EC - Directive 2007/46/EC of the European Parliament and of the Council of 5 September 2007 establishing a framework for the approval of motor vehicles and their trailers, and of systems, components and separate technical units intended for such vehicles (Framework Directive). European Aluminium Association. 2014. "Moving up to aluminium. High payload, safe and sustainable road transport." June 2014. https://www.europeanaluminium.eu/media/1037/moving-up-toaluminium-2014.pdf.

European Commission. 2020. "Environment." Accessed April 20, 2020. https://ec.europa.eu/ environment/waste/elv/index.htm.

Kanari, Ndue, Jean-Louis Pineau, and Seit Shallari. 2003. "End-of-life vehicle recycling in the European Union." JOM: The Journal of The Minerals, Metals \& Materials Society 55(8): 15-19. https://doi.org/10.1007/s11837-003-0098-7.

Monier, Véronique, Katherine Salès, Lorna Lucet, and Radia Benhallam. 2017. End-of-life vehicle. Annual Report - Data 2015. ADEME.

Prochowski, Leon, i Andrzej Żuchowski. 2004. Samochody ciężarowe i autobusy. Warszawa: Wydawnictwa Komunikacji i Łączności.

Recykling-polska.pl. 2020. Recykling. Nauka i technologia. Dostęp 17.04.2020. https://www. recykling-polska.pl/450/informacje-recykling/ rodzaje-recyklingu-samochodow/.

Regulation 678/2011 - Commission Regulation (EU) No 678/2011 of 14 July 2011 replacing Annex II and amending Annexes IV, IX and XI to Directive 2007/46/EC of the European Parliament and of the Council establishing a framework for the approval of motor vehicles and their trailers, and of systems, components and separate technical units intended for such vehicles (Framework Directive).

Scania. 2015. "The evolution of truck materials." Published April 30, 2015. https://www.scania.com/ group/en/the-evolution-of-truck-materials/.

Scaniausedparts.com. 2020. Scania Vehicle Recycling. Accessed May 11, 2020. https://www. scaniausedparts.com/en/about-us.

Services Man, 2020a. "Second Hand, First Choice: Man Genuine Parts Ecoline." Accessed May 12, 2020. https://www.services.man.eu/sa/en/mangenuine-parts-ecoline-373509.html.

Services Man, 2020b. "A Clever Remanufactured Parts Programme. Man Genuine Parts Ecoline.” 
Accessed May 12, 2020. https://www.services.man. $\mathrm{eu} / \mathrm{man} / \mathrm{media} / \mathrm{content}$ _medien/doc/business_ websites_middle_east/2017_01_MAN_MTB_ME_ ActiveParts_Flyer_Ecoline_Web.pdf.

Synák, František, Ján Gaňa, Vladimír Rievaj, and Lenka Mokričková. 2019. "Ways of reducing carbon dioxide from road transport." The Archives of Automotive Engineering 86(4): 41-54. https://doi. org/10.14669/AM.VOL86.ART3.
Toyota Europe. "Vehicle recycling." Accessed April 17, 2020. https://www.toyota-europe.com/ world-of-toyota/feel/environment/better-earth/ recycle.

Volvo Truck Corporation. "Recycling can give an old truck a new lease of life." Accessed May 11, 2020. https://www.volvogroup.se/content/dam/volvo/ volvo-group/markets/sweden/sv-se/news/2011/ Recyc_en.pdf. 